\title{
Morphology, reproduction and development of Hypoglossum hypoglossoides (Stackhouse) Collins \& Hervey (Ceramiales, Rhodophyta) from the south and southeastern Brazilian coast
}

\author{
PAULO A. HORTA ${ }^{1,4}$, NAIR S. YOKOYA ${ }^{2}$, SILVIA M.P.B. GUIMARÃES ${ }^{2}$, DENISE S. BACCI ${ }^{2}$ and \\ EURICO C. OLIVEIRA ${ }^{3}$
}

(received: January 15, 2003; accepted: September 2, 2003)

\begin{abstract}
Morphology, reproduction and development of Hypoglossum hypoglossoides (Stackhouse) Collins \& Hervey (Ceramiales, Rhodophyta) from the south and southeastern Brazilian coast). Hypoglossum hypoglossoides (Stackhouse) Collins \& Hervey is reported for the first time from the infralittoral of São Paulo and Santa Catarina states. The species was already reported to the states of Rio de Janeiro, Espírito Santo and Bahia as Hypoglossum tenuifolium (Harvey) J. Agardh var. carolinianum Williams. A detailed description of the morphology and reproduction is given based on field-collected material. Unialgal cultures were initiated from tetraspore germination, and growth rates of gametophytes were determined under different conditions of temperature, photoperiod and irradiance. Gametophytes grew well between 15 to $30^{\circ} \mathrm{C}, 14 \mathrm{~L}: 10 \mathrm{D}$ and $10 \mathrm{~L}: 14 \mathrm{D}$ photoperiods and irradiance from 20 to $120 \mu \mathrm{mol}$ photons. $\mathrm{m}^{-2} \cdot \mathrm{s}^{-1}$, but presented low percentage of fertile plants in low temperature $\left(15^{\circ} \mathrm{C}\right)$. Gametophytes cultured in laboratory developed only male reproductive structures. Physiological responses of $H$. hypoglossoides indicate that the species is well adapted to temperature and light variations which could explain its range of vertical (6-26 m depth) and latitudinal distribution (from Fernando de Noronha to Santa Catarina) as well as the absence of sexual reproduction in the southern limit of its distribution.
\end{abstract}

Key words - Delesseriaceae, development, Hypoglossum hypoglossoides, reproduction, Rhodophyta

RESUMO - (Morfologia, reprodução e desenvolvimento de Hypoglossum hypoglossoides (Stackhouse) Collins \& Hervey (Ceramiales, Rhodophyta) da costa sul e sudeste do Brasil). Hypoglossum hypoglossoides (Stackhouse) Collins \& Hervey é descrito pela primeira vez para o infralitoral dos estados de São Paulo e Santa Catarina. A espécie já foi descrita para os estados do Rio de Janeiro, Espírito Santo e Bahia como Hypoglossum tenuifolium (Harvey) J. Agardh var. carolinianum Williams. Uma descrição detalhada da morfologia e reprodução da espécie é apresentada com base em material de campo. Cultivos unialgais foram estabelecidos a partir da germinação de tetrásporos e a taxa de crescimento de gametófitos foi determinada em diferentes condições de temperatura, fotoperíodo e irradiância. Os gametófitos toleraram as variações de temperatura de 15 a $30^{\circ} \mathrm{C}$, fotoperíodos de 14L:10E e 10L:14E e irradiâncias de 20 a $120 \mu$ mol fótons. $\mathrm{m}^{-2} \cdot \mathrm{s}^{-1}$, mas apresentaram baixa percentagem de plantas férteis quando cultivados em baixa temperatura $\left(15^{\circ} \mathrm{C}\right)$. Gametófitos cultivados em laboratório desenvolveram somente estruturas masculinas. As respostas fisiológicas de $H$. hypoglossoides indicam que a espécie está bem adaptada às variações de temperatura e luz , o que pode explicar a sua ampla distribuição vertical (6-26 m de profundidade), distribuição latitudinal (Fernando de Noronha a Santa Catarina), assim como a ausência de plantas férteis no seu limite sul de distribuição.

Palavras-chave - Delesseriaceae, desenvolvimento, Hypoglossum hypoglossoides, reprodução, Rhodophyta

\section{Introduction}

The genus Hypoglossum Kützing is represented by 28 species, mostly from warm waters (Wynne \& Kraft 1985, Wynne \& Ballantine 1986, Zheng 1998,

\footnotetext{
1. Universidade Federal de Santa Catarina, Centro de Ciências Agrárias, Departamento de Aquicultura, Caixa Postal 476, 88040-900 Florianópolis, SC, Brazil.

2. Instituto de Botânica, Seção de Ficologia, Caixa Postal 4005, 01061-970 São Paulo, SP, Brazil.

3. Universidade de São Paulo, Instituto de Biociências, Departamento de Botânica, Caixa Postal 11461, 05422-970 São Paulo, SP, Brazil.

4. Corresponding author: pahorta@cca.ufsc.br, pahorta@uol.com.br
}

Wynne \& De Clerck 2000, Stegenga et al. 2001). It is characterised by having initials of all third-order cell rows reaching the margin of blades, carposporangia formed in chains, tetrasporangia produced from cells of second and third-order rows, and absence of intercalary divisions (Womersley \& Shepley 1982).

The genus is represented in Brazil by three species, the present one (Oliveira Filho 1969, Yoneshigue 1985, as Hypoglossum tenuifolium (Harvey) J. Agardh var. carolinianum Williams), H. anomalum Wynne \& Ballantine (Horta \& Oliveira 2001) and H. tenuifolium (Harvey) J. Agardh var. tenuifolium (Cordeiro-Marino \& Guimarães 1981). 
The relatively broad vertical and latitudinal distribution of Hypoglossum hypoglossoides in Brazil led us to study the effects of light and temperature on its growth and reproduction. Additionally we present a detailed description of the morphology and reproduction of $H$. hypoglossoides.

\section{Material and methods}

Collections were carried out by scuba diving (6-26 m), in the south and southeastern coast of Brazil. Field-collected plants were preserved in formalin $4 \%$ in seawater, stained with aniline blue $1 \%$, acidified with $1 \mathrm{~N} \mathrm{HCl}$, and mounted in $50 \%$ Karo Syrup. The photographs were taken on a standard Leica microscope. The studied specimens were deposited as slides (PH) in the Phycological Herbarium of the University of São Paulo (SPF), Brazil.

For laboratory culture studies, fertile tetrasporophytes were collected at Rapada Island, Ubatuba, SP (23 $26^{\prime}$ S and $44^{\circ} 54^{\prime}$ W), in April/1999, at around $10 \mathrm{~m}$ depth. Voucher specimens were deposited in the herbarium of Institute of Botany, Brazil (access number: SP 355789). Unialgal cultures were initiated by tetraspore germination, and cultivated in Von Stosch's enriched seawater (VSES) at full strength (Edwards 1970) with vitamin concentrations reduced to 50\%. Germanium dioxide (1.0 mg.L $\left.\mathrm{L}^{-1}\right)$ was added to the VSES to supress diatom growth. Standard culture conditions were: salinity $30 \pm 1 \mathrm{psu}$, temperature of $24 \pm 2{ }^{\circ} \mathrm{C}, 40.0-50.0 \mu \mathrm{mol}$ photons. $\mathrm{m}^{-2} \cdot \mathrm{s}^{-1}$ provided by cool-white fluorescent lamps with 14L:10D photoperiod (light:dark cycle), without aeration. Photon irradiance was measured with a LI-COR 250 quantameter equipped with underwater quantum sensor (LI-192 SA, LI-COR, Inc.). Culture medium was renewed weekly.

The effects of temperatures of $15,20,25$ and $30^{\circ} \mathrm{C}$ under photoperiod of 14L:10D (light:dark cycle) and temperatures of 20 and $30^{\circ} \mathrm{C}$ under photoperiod of 10L:14D (light:dark cycle) were tested under photon irradiances of 40.0-50.0 $\mu \mathrm{mol}$ photons. $\mathrm{m}^{-2} \cdot \mathrm{s}^{-1}$. The experiment of photon irradiance variation (from 20 to $120 \mu \mathrm{mol}$ photons. $\mathrm{m}^{-2} \cdot \mathrm{s}^{-1}$ ) was conducted at $20^{\circ} \mathrm{C}$ and 14L:10D photoperiod. Other experimental conditions were the same as those described above for unialgal cultures. Each treatment was tested with three replicates of 10 gametophytic blades (3-5 mm length) inoculated into $250 \mathrm{~mL}$ conical flasks containing $150 \mathrm{~mL}$ of VSES.

Measurements of blade length and observation on reproductive structures, as well as medium renewal were made weekly. Growth rate was calculated as $\left[\ln \left(\mathrm{L}_{\mathrm{t}} \cdot \mathrm{L}_{\mathrm{o}}{ }^{-1}\right) \cdot \mathrm{t}^{-1}\right] \cdot 100 \%$, where $L_{o}$ is the initial blade length, $L_{t}$ is the blade length after $t$ days, and $t$ is the number of days. Growth rates were calculated after 21 days, when plants were in a vegetative phase. Analysis of variance with one factor was performed on growth rate data.

\section{Results}

Hypoglossum hypoglossoides (Stackhouse) Collins \& Hervey, Proc. Amer. Acad., Arts Sci. 53:116. 1919.

Basionym: Fucus hypoglossoides Stackhouse, Nereis Britannica 3:76. 1802 (“1801”).

Studied material: BRAZIL: Rio DE JANeIRo: Emboassica Island, X-1998, P. Horta (PH 28); Porcos Island, X-1998, P. Horta (PH 118-125). São PaUlo: Rapada Island, IV-1999, P. Horta (PH 12); Queimada Grande Island, VII-1997, P. Horta (PH 491); Laje de Santos, XI-1998, P. Horta (PH 492). Santa Catarina: Arvoredo Island, I-1998, P. Horta (PH 495).

Field material description - Rosy delicate plants, $1-4 \mathrm{~cm}$ in height, growing erect as epiphyte or epilithic on rock or shell fragments. Blade monostromatic except at the midrib, $1-3 \mathrm{~mm}$ wide at the median portion and 0.3-0.7 $\mathrm{mm}$ at the base. Cortication restrict to the basal cylindrical portions. Branches single or in opposite pairs originating from the midrib axial cell. Midrib with elongated axial cells, 105-225 $\mu \mathrm{m}$ long; in superficial view midrib with three cells on the distal portion and five cells on the basal portion. The monostromatic region is made out by second and third-order rows, composed of irregular hexagonal cells disposed obliquely to the margin in surface view. All cells of the second-order rows give rise to third-order rows (type-1 apex). Growth in length takes place by transversely dividing apical cell in the terminal portion of each branch.

Tetraporangia tetrahedrally divided, $22-54 \mu \mathrm{m}$ in diameter, randomly distributed in one-two pairs of opposite sori or in unilateral sori, $0.6-1.5 \mathrm{~mm}$ long and 150-380 $\mu \mathrm{m}$ wide. Lateral pericentral cells are not directly involved in tetrasporangia formation (figures 1-5).

Gametangial thalli dioecious. Female plants with procarps distributed along the midrib, with four-celled carpogonial branch L-shaped, with the second cell larger than the others with ca. $7 \mu \mathrm{m}$ in diameter. Cystocarp projecting on the midrib, in series or isolated, $330-820 \mu \mathrm{m}$ in the larger diameter. Carposporangia with $29-58 \mu \mathrm{m}$ in the larger diameter (figures 6-8). Spermatangial sori oblique, distributed along both sides of midrib, originated from cells of second and third-order filaments. Male plants are usually smaller and less branched (figures 9-12).

Germination of tetraspore and tetrasporeling development in laboratory culture - Tetraspores attach and soon divide into two unequal cells, one of which becomes the rhizoid initial and the other divides to 


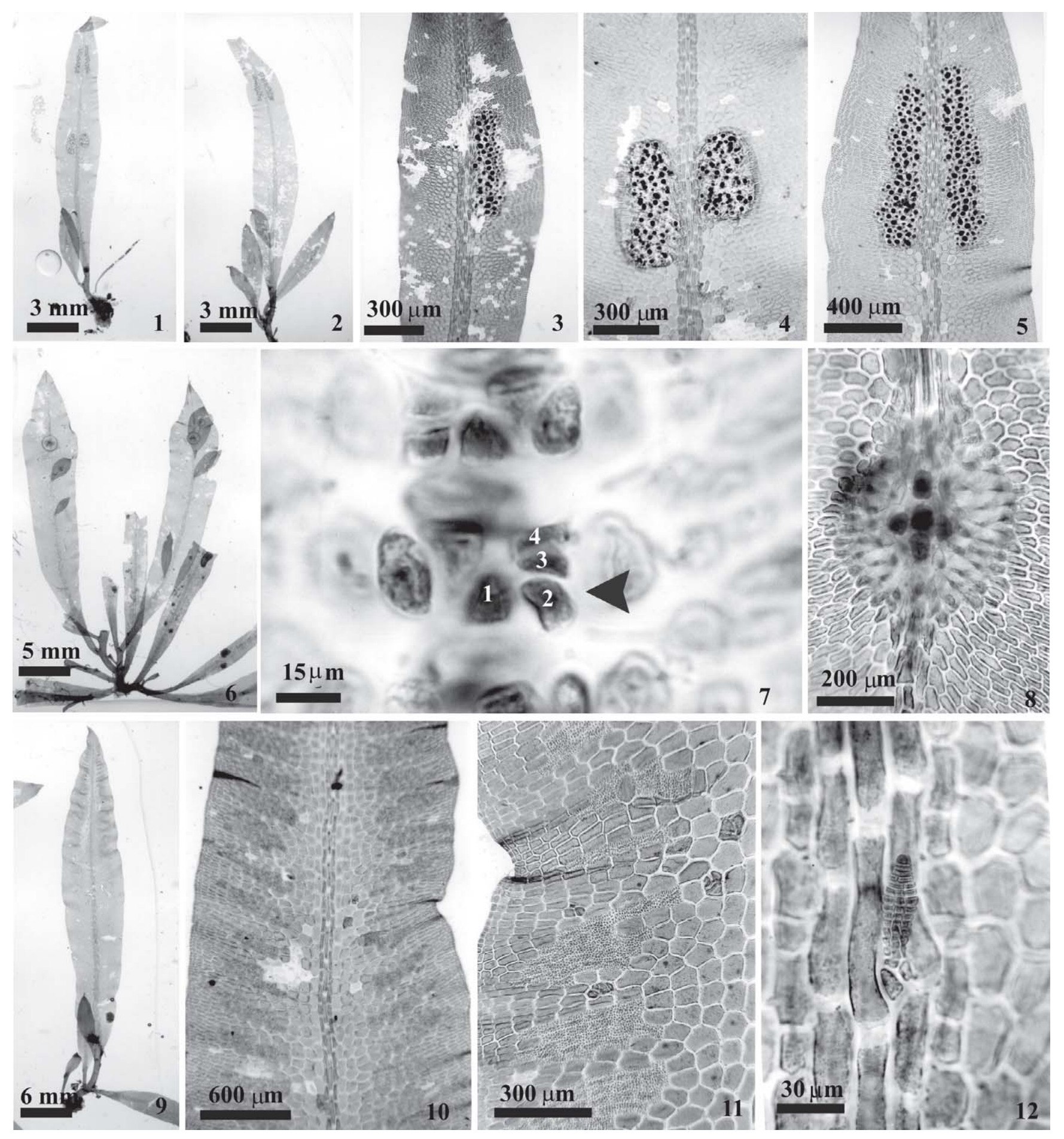

Figures 1-12. Morphology and reproduction of Hypoglossum hypoglossoides from field-collected material. 1-2. General aspect of tetrasporic plants. 3-5. Detail of tetrasporangial sori. 6. General aspect of female plant. 7. Detail of four-celled carpogonial branch, with the second cell larger than the others (arrowhead). 8. Detail of a cystocarp, showing four gonimoblast initial cells. 9. General aspect of a male plant. 10-11. Different aspects of spermatangial sori. 12. Young branch produced from midrib. 
produce an axial cell row (figures 13-16); pericentral cells are cut from the third to the fifth segments behind the apical cell (figures 17-21).

Development of gametophytes in laboratory culture Growth rates of gametophytes varied from $5.2 \% . \mathrm{d}^{-1}$ to $7.7 \% . \mathrm{d}^{-1}$, with the highest growth rate at $30^{\circ} \mathrm{C} / 10 \mathrm{~L}: 14 \mathrm{D}$ (figure 22). However, the differences among treatments were not significant $(\mathrm{F}=0.52)$. Gametophytes developed spermatangial sori after three weeks of culturing in all treatments (figure 23), and the highest percentage of male plants was induced by $20^{\circ} \mathrm{C} / 10 \mathrm{~L}: 14 \mathrm{D}$, and high temperature $\left(30{ }^{\circ} \mathrm{C}\right)$ in both photoperiods. Low percentage of male plants was observed at $15^{\circ} \mathrm{C}$ (figure 23). Development of spermatangial sori was observed in all gametophytes cultured under irradiances from 20 to $120 \mu \mathrm{mol}$ photons. $\mathrm{m}^{-2} \cdot \mathrm{s}^{-1}$ after three weeks. Growth rates of fertile male gametophytes varied from $1.9 \% . \mathrm{d}^{-1}$ to $3.0 \% . \mathrm{d}^{-1}$ (figure 24 ). However, differences among treatments were not significant $(\mathrm{F}=0.74)$.

In cultured male gametophytes, spermatangial sori are produced on both sides of the midrib and are separated by rows of sterile cells (figures 25-26). Some sterile cells divided and gave rise to new erect blades (figures 27-28) resembling the early stages of tetrasporeling development (figures 19-21). Carpogonial branches were not observed in our cultures and the lifehistory of Hypoglossum hypoglossoides was not completed in laboratory.

\section{Discussion}

Our plants fit well in the genus Hypoglossum, exhibiting its diagnostic features of a third-order cell row produced from every cell of the second-order row, blades typically elongated and attenuated, and tetrasporangia arranged irregularly in sori (Wynne \& Ballantine 1986, Wynne 1988).

Our material of Hypoglossum hypoglossoides presents type-1 apex (sensu Wynne et al. 1989), corticated midribs at least in lower portions of blades, tetrasporangia in linear sori separated from the midrib of ordinary blades by sterile cells and sori present mostly in both sides of the midrib (Wynne 1984, Schneider \& Searles 1991, Schneider 2000, Wynne \& De Clerck 2000).

Among the 26 species listed in the key proposed by Wynne \& De Clerck (2000), the taxon with great
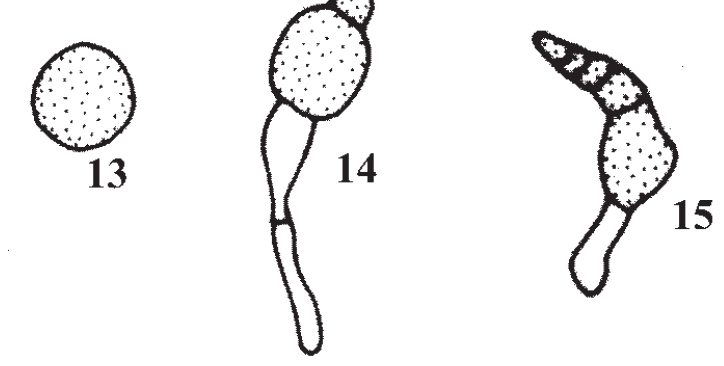

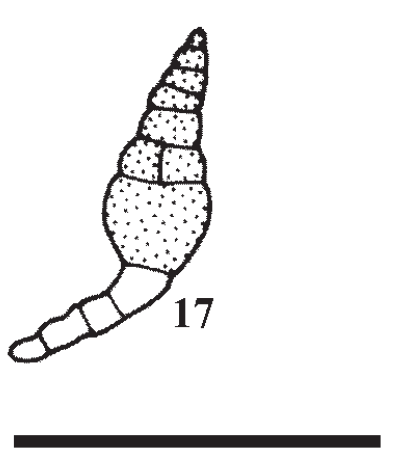

$200 \mu \mathbf{m}$
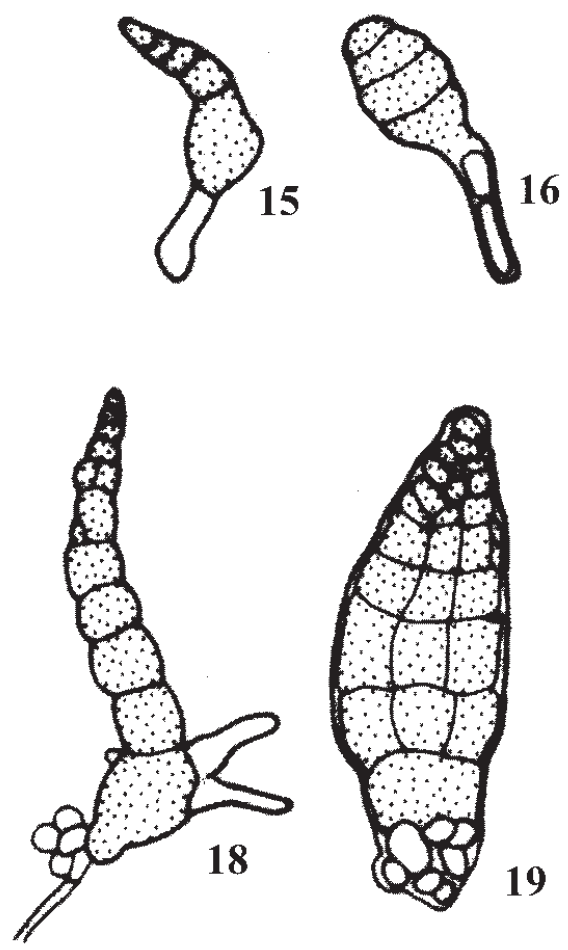

19
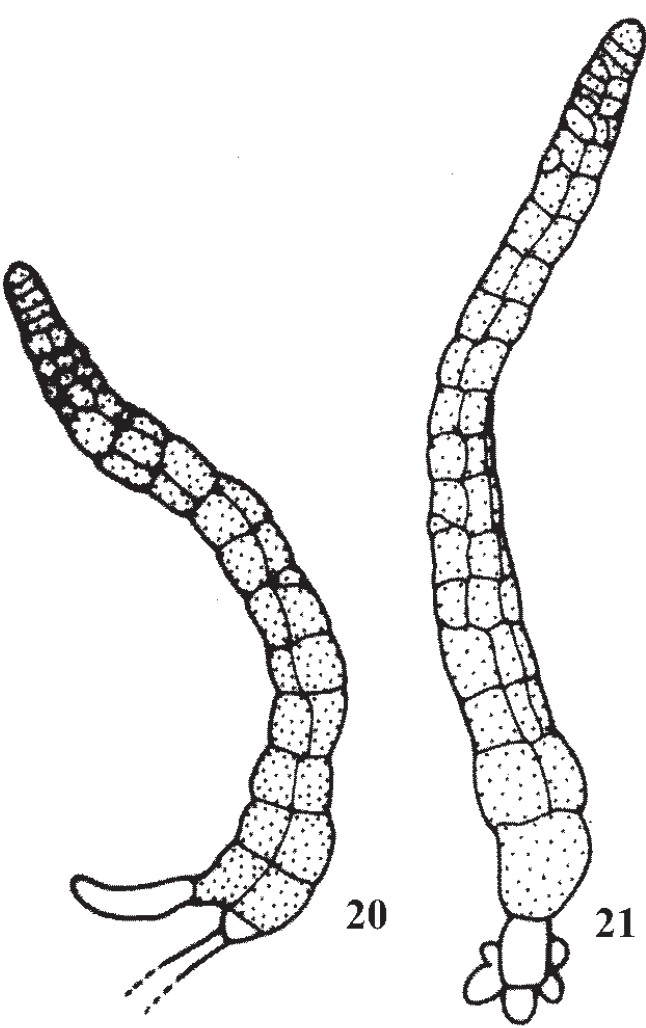

Figures 13-21. Tetraspore germination and tetrasporeling development of Hypoglossum hypoglossoides in laboratory conditions (salinity of $30 \pm 1 \mathrm{psu}$, temperature of $24 \pm 2^{\circ} \mathrm{C}$, photon irradiance of $40.0-50.0 \mu \mathrm{mol}$ photons. $\mathrm{m}^{-2} \cdot \mathrm{s}^{-1}, 14 \mathrm{~L}: 10 \mathrm{D}$ photoperiod, and culture medium with Von Stosch's nutrient solution). 13. Liberated tetraspore. 14-21. Different stages of tetrasporeling development with one to seven-days old. 


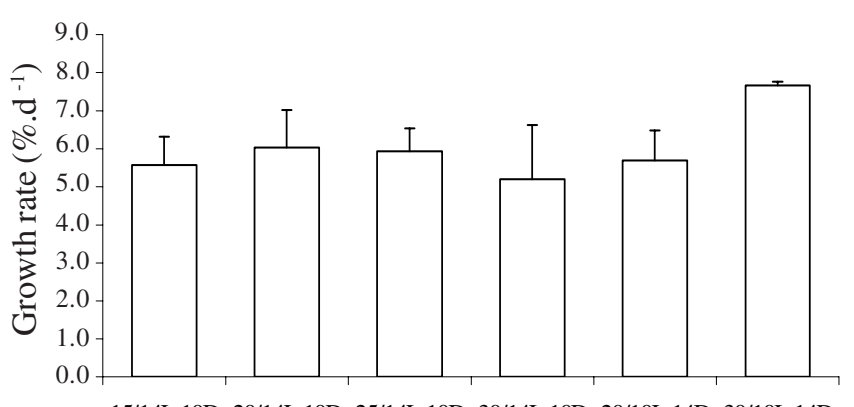

15/14L:10D 20/14L:10D 25/14L:10D 30/14L:10D 20/10L:14D 30/10L:14D

Temperature $\left({ }^{\circ} \mathrm{C}\right) /$ Photoperiod (h)

Figure 22. Growth rates of gametophytic blades of Hypoglossum hypoglossoides cultured in different temperatures and photoperiods for three weeks. Each data point is the mean of three replicates. Experiment was conducted in salinity of $30 \pm 1 \mathrm{psu}$, photon irradiance of 40.0-50.0 $\mu \mathrm{mol}$ photons. $\mathrm{m}^{-2} . \mathrm{s}^{-1}$, and culture medium with Von Stosch's nutrient solution.

similarity to our specimens is Hypoglossum androlamellare Wynne \& De Clerck. However, this species, described from Tanzania, presents spermatangial sori in a chevron arrangement, whereas in $H$. hypoglossoides the male structures are represented by interrupted or continuous sori.

Hypoglossum imperfectum Stegenga, Anderson \& Bolton (Stegenga et al. 2001), recently described to

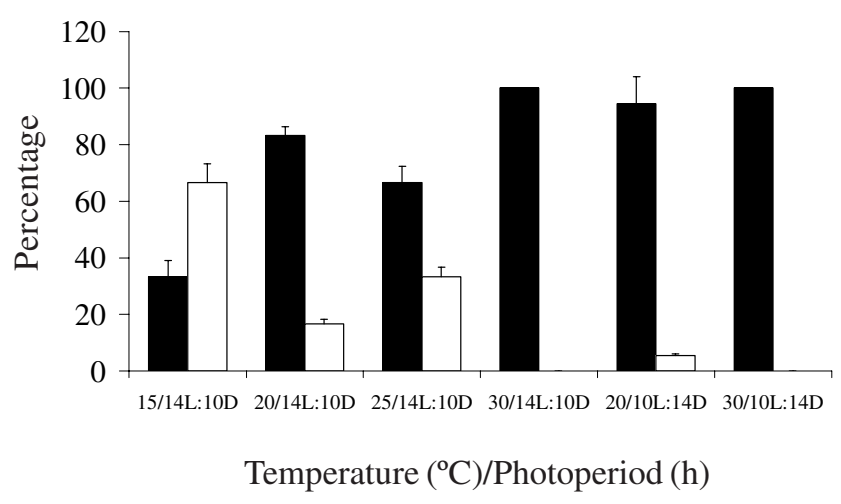

Figure 23. Development of reproductive structures on gametophytic blades of Hypoglossum hypoglossoides cultured in different temperatures and photoperiod for five weeks. Percentage corresponds to the number of blades with reproductive structures per total number of blades. Experiment was conducted in salinity of $30 \pm 1 \mathrm{psu}$, photon irradiance of 40.0-50.0 $\mu \mathrm{mol}$ photons. $\mathrm{m}^{-2} . \mathrm{s}^{-1}$, and culture medium with Von Stosch's nutrient solution. $\square=$ Non fertile plants; = Male plants.
South Africa, differs from our specimens by its prostrate habit and incomplete third-order cell rows, while $H$. hypoglossoides has erect frond with all third-order cell row reaching the thallus margin.

The material identified as Hypoglossum tenuifolium var. tenuifolium by Cordeiro-Marino \& Guimarães (1981) differs from our specimens because third-order cell rows are not produced from every cell of the second-order rows.

The plants referred as Hypoglossum tenuifolium (Harvey) J. Agardh var. carolinianum Williams from the coasts of Espírito Santo (Oliveira Filho 1969), Bahia (Oliveira et al. 1979, Nunes 1998), and Rio de Janeiro (Yoneshigue 1985, Pedrini et al. 1992) are better placed into $H$. hypoglossoides. This variety was considered as a synonym of $H$. hypoglossoides by Wynne \& Ballantine (1986) due to the fact that all cells of the second-order rows give rise to the initial cells of the third-order rows.

Our material was frequent in all the studied area, being found from 6-26 $\mathrm{m}$ depth. Tetrasporangial and sexual plants were found in Rio de Janeiro and in the northern localities of São Paulo state. Fertile plants were not found at Santa Catarina state which corresponds to the southern limit of Hypoglossum hypoglossoides distribution in western Atlantic. These data could be related to the temperature responses of cultured gametophytes, which presented lower percentage of male plants in low temperature $\left(15^{\circ} \mathrm{C}\right)$.

Gametophytes of Hypoglossum hypoglossoides tolerated the tested variations of temperature, photoperiod and irradiance. Our experimental data show

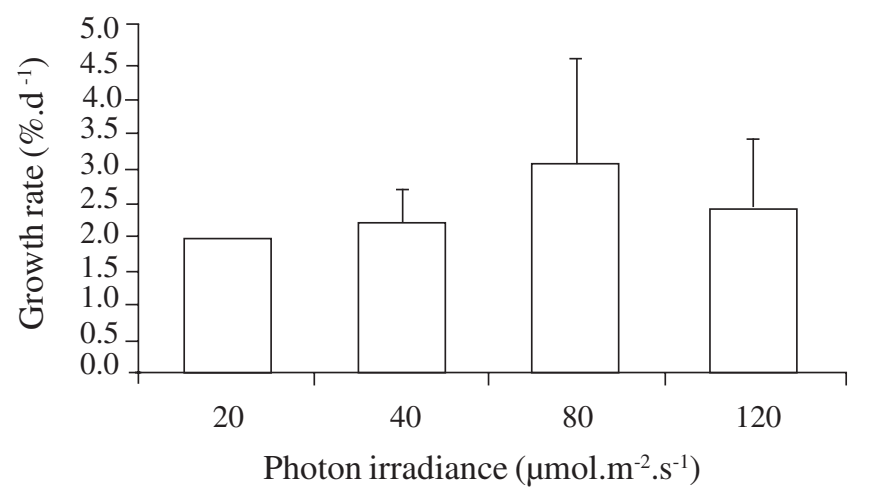

Figure 24. Growth rates of gametophytic blades of Hypoglossum hypoglossoides cultured in different photon irradiances for three weeks. Each data point is the mean of three replicates. Experiment was conducted in salinity of $30 \pm$ $1 \mathrm{psu}$, temperature of $24 \pm 2{ }^{\circ} \mathrm{C}, 14 \mathrm{~L}$ :10D photoperiod, and culture medium with Von Stosch's nutrient solution. 

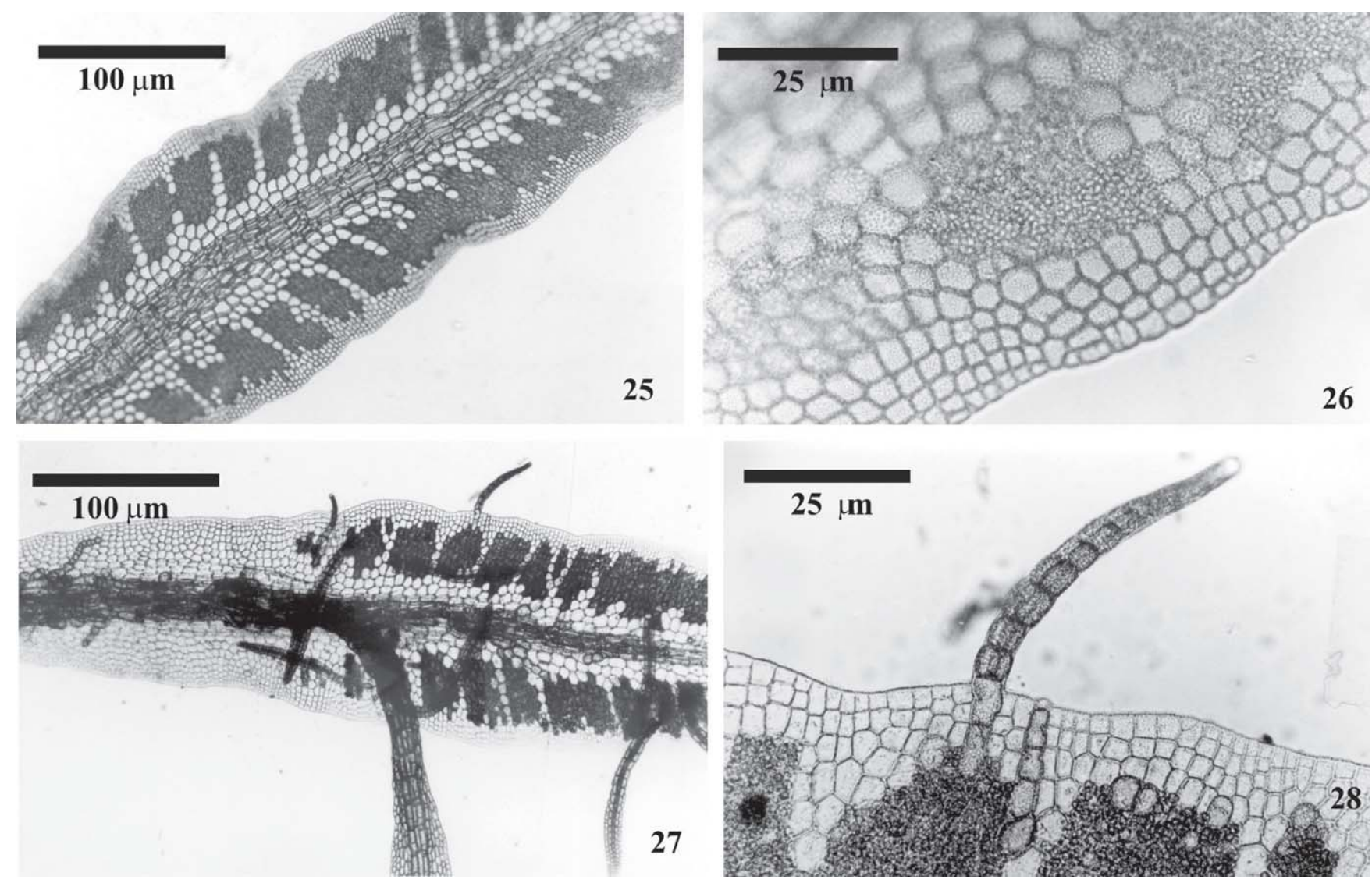

Figures 25-28. Cultured male gametophytes of Hypoglossum hypoglossoides in laboratory conditions (salinity of $30 \pm 1$ psu, temperature of $24 \pm 2{ }^{\circ} \mathrm{C}$, photon irradiance of $40.0-50.0 \mu \mathrm{mol}$ photons. $\mathrm{m}^{-2} \cdot \mathrm{s}^{-1}, 14 \mathrm{~L}: 10 \mathrm{D}$ photoperiod, and culture medium with Von Stosch's nutrient solution). Figure 25. General aspect of blade with spermatangial sori. 26. Detail of a spermatangial sorus. 27. General aspect of a blade with the formation of new erect thalli. 28. Detail of the formation of new erect blades.

that $H$. hypoglossoides is well adapted to the temperature and light variations expected to be found in its regions of occurrence in Brazil. The range of temperature tolerance of $\mathrm{H}$. hypoglossoides (from 15 to $30^{\circ} \mathrm{C}$ ) is similar to the data obtained for other Brazilian red algae as Hypnea cornuta (Lamour.) J. Agardh and Pterocladiella capillacea (S.G. Gmel.) Santel. \& Hommers. (Yokoya \& Oliveira 1992), and colour strains of H. musciformis (Wulfen in Jacqu.) J.V. Lamour. (Yokoya et al. 2003).

The tetraspore germination pattern described in the present study corresponds to the "Ceramiumtype" (Dixon 1973), and is similar to the germination pattern observed for Hypoglossum nipponicum Yamada (Notoya 1986) and H. rhizophorum Ballantine \& Wynne (Ballantine \& Wynne 1988).

A "Polysiphonia-type" life-history was expected for our plants as have been determined for other
Delesseriaceae genera (Yarish \& Edwards 1982, Kamiya et al. 1995, West et al. 2001), and for species of Hypoglossum (Notoya 1986, Ballantine \& Wynne 1988). Nevertheless, the life-history of $H$. hypoglossoides was not completed because only male plants were produced from the tetrasporederived plants. Cultured gametophytes of $H$. nipponicum and $H$. rhizophorum were dioecious, and developed approximately equal numbers of male and female plants (Notoya 1996, Ballantine \& Wynne 1988). Deviation observed in $H$. hypoglossoides could be related to the lack of aeration in the cultures. The occurrence of spermatangia and tetrasporangia in carpospore-derived plants and only spermatangia in tetraspore-derived plants of Gracilaria chilensis Bird, McLachlan \& Oliveira were related to the presence or absence of aeration, and these results could be explained by the interference of 
environmental factors in genetic expression of the spores (Plastino \& Oliveira 1988). Similarly, genetic characteristic or specific environmental conditions could regulate the reproductive development of $H$. hypoglossoides, as the occurrence of exclusive asexual reproduction in some populations of Caloglossa leprieurii (Montagne) G. Martens (West et al. 2001).

The present study describes for the first time the occurrence of Hypoglossum hypoglossoides from the littoral of São Paulo and Santa Catarina states, the latter being its southern limit in the American Atlantic.

Acknowledgements - The authors are grateful to CNPq for providing grants. This research was partially supported through the program Biota-Fapesp (98/04955-3).

\section{References}

BALLANTINE, D.L. \& WYNNE, M.J. 1988. The life history and development of Hypoglossum rhizophorum (Delesseriaceae, Rhodophyta) in culture, a new deepwater species from the Caribbean. Journal of Phycology 24:8-12.

CORDEIRO-MARINO, M. \& GUIMARÃES, S.M.P.B. 1981. Novas referências para a flora marinha de profundidade do Brasil. Rickia 9:61-70.

DIXON, P.S. 1973. Biology of the Rhodophyta. Oliver \& Boyd, Edinburgh.

EDWARDS, P. 1970. Illustrated guide to the seaweeds and seagrasses in the vicinity of Porto Aransas, Texas. Contributions to Marine Science, University of Texas at Austin 15:1-228.

HORTA, P.A. \& OLIVEIRA, E.C. 2001. Some Delesseriaceae (Ceramiales, Rhodophyta) new to the southwestern Atlantic. Revista Brasileira de Botânica 24:447-454.

KAMIYA, M., TANAKA, R. \& HARA, Y. 1995. A morphological study and hybridization analysis of Caloglossa leprieurii (Ceramiales, Rhodophyta) from Japan, Singapore and Australia. Phycological Research 43:81-91.

NOTOYA, M. 1986. Hypoglossum nipponicum Yamada (Delesseriaceae, Rhodophyta) in culture. Japanese Journal of Phycology 34:28-30.

NUNES, J.M.C. 1998. Catálogo de algas marinhas bentônicas do Estado da Bahia, Brasil. Acta Botanica Malacitana 23:5-21.

OLIVEIRAFILHO, E.C. 1969. Algas marinhas do sul do Estado do Espírito Santo (Brasil). I - Ceramiales. Boletim da Faculdade de Ciências e Letras da Universidade de São Paulo 343:1-277.

OLIVEIRA FILHO, E.C., UGADIM, Y. \& PAULA, E.J. 1979. Comunidades associadas a plantas de Sargassum flutuantes em águas da corrente do BrasilConsiderações biogeográficas. Boletim de Botânica da Universidade de São Paulo 7:5-9.

PEDRINI, A.G., UGADIM, Y. \& BRAGA, M.R.A. 1992.Algas marinhas bentônicas do arquipélogo de Fernando de Noronha, Brasil. Boletim de Botânica da Universidade de São Paulo 13:93-101.

PLASTINO, E.M. \& OLIVEIRA, E.C. 1988. Deviations in the life-history of Gracilaria sp. (Rhodophyta, Gigartinales), from Coquimbo, Chile, under different culture conditions. Hydrobiologia 164:67-74.

SCHNEIDER, C.W. 2000. Notes on the marine algae of the Bermudas. 5. Some Delesseriaceae (Ceramiales, Rhodophyta), including the first record of Hypoglossum barbatum Okamura from the Atlantic Ocean. Botanica Marina 43:455-466.

SCHNEIDER, C.W. \& SEARLES, R.B. 1991. Seaweeds of the southeastern United States: Cape Hatteras do Cape Canaveral. Duke University Press, Duke.

STEGENGA, H., ANDERSON, R.J. \& BOLTON, J.J. 2001. Hypoglossum imperfectum (Rhodophyta, Delesseriaceae) from the South African South Coast. Botanica Marina 44:157-162.

WEST, J.A., ZUCCARELLO, G.C. \& KAMIYA, M. 2001. Reproductive patterns of Caloglossa species (Delesseriaceae, Rhodophyta) from Australia and New Zealand: multiple origins of asexuality in C. leprieurii. Literature review on apomixis, mixed-phase, bisexuality and sexual compatibility. Phycological Research 49:183-200.

WOMERSLEY, H.B.S. \& SHEPLEY, E.A. 1982. Southern Australian species of Hypoglossum (Delesseriaceae, Rhodophyta). Australian Journal of Botany 30:321-346.

WYNNE, M.J. 1984. The correct name for the type of Hypoglossum Kützing (Delesseriaceae, Rhodophyta). Taxon 33:85-87.

WYNNE, M.J. 1988. A reassessment of the Hypoglossum group (Delesseriaceae, Rhodophyta), with a critique of its genera. Helgoländer Wissenschatliche Meeresuntersuchungen 42:511-534.

WYNNE, M.J. \& BALLATINE, D.L. 1986. The genus Hypoglossum Kützing (Delesseriaceae, Rhodophyta) in the tropical western Atlantic, including $H$. anomalum sp. nov. Journal of Phycology 22:185-193.

WYNNE, M.J. \& DE CLERCK, O. 2000. Taxonomic observations on Hypoglossum (Delesseriaceae, Rhodophyta) in the indian Ocean and Malayan region, including the description of two new species. Cryptogamie, Algologie 21:111-131.

WYNNE, M.J. \& KRAFT, G.T. 1985. Hypoglossum caloglossoides sp. nov. (Delesseriaceae, Rhodophyta) from Lord Howe Island, South Pacific. British Phycological Journal 20:9-19.

WYNNE, M.J., PRICE, I.R. \& BALLANTINE, D.L. 1989. Distinctions between Hypoglossum barbatum 
Okamura, H. minimum Yamada and $H$. simulans sp.nov. (Delesseriaceae, Rhodophyta). Phycologia 28:28-38.

YARISH, C. \& EDWARDS, P. 1982. A field and cultural investigation of the horizontal and seasonal distribution of estuarine red algae of New Jersey. Phycologia 21:112-124.

YOKOYA, N.S. \& OLIVEIRA, E.C. 1992. Temperature responses of economically important red algae and their potential for mariculture in Brazilian waters. Journal of Applied Phycology 4: 339-345.

YOKOYA, N.S., PLASTINO, E.M. \& ARTEL, R. 2003. Physiological responses and pigment characterization of two colour strains of the carrageenophyte Hypnea musciformis (Rhodophyta). In Proceedings of the XVII ${ }^{\text {th }}$ International Seaweed Symposium (A.R.O. Chapman, R.J. Anderson, V. Vreeland \& I. Davison, eds.). Oxford University Press, New York. p.425-434.

YONESHIGUE, Y. 1985. Taxonomie et ecologie des algues marines dans la region de Cabo Frio (Rio de Janeiro, Brésil). Thèse de Docteur, Université d'Aix-Marseille, Marseille.

ZHENG, Y. 1998. Hypoglossum fujianensis sp. nov. (Delesseriaceae, Rhodophyta) from Fujian coast, China. Chinese Journal of Oceanology and Limnology 16:369-372. 